\title{
Public Expenditure and Economic Growth Relationship: Further Evidence from Nigerian Context
}

\author{
Nnachi Egwu Onuoha, Gregory Onuora Okoye
}

To Link this Article: http://dx.doi.org/10.6007/IJARBSS/v10-i11/8129

DOI:10.6007/IJARBSS/v10-i11/8129

Received: 20 September 2020, Revised: 19 October 2020, Accepted: 10 November 2020

Published Online: 28 November 2020

In-Text Citation: (Onuoha, \& Okoye, 2020)

To Cite this Article: Onuoha, N. E., \& Okoye, G. O. (2020). Public Expenditure and Economic Growth Relationship: Further Evidence from Nigerian Context. International Journal of Academic Research in Business and Social Sciences. 10(11), 616-627.

Copyright: (c) 2020 The Author(s)

Published by Human Resource Management Academic Research Society (www.hrmars.com) This article is published under the Creative Commons Attribution (CC BY 4.0) license. Anyone may reproduce, distribute, translate and create derivative works of this article (for both commercial and non-commercial purposes), subject to full attribution to the original publication and authors. The full terms of this license may be seen at: http://creativecommons.org/licences/by/4.0/legalcode

Vol. 10, No. 11, 2020, Pg. 616 - 627

Full Terms \& Conditions of access and use can be found at http://hrmars.com/index.php/pages/detail/publication-ethics 


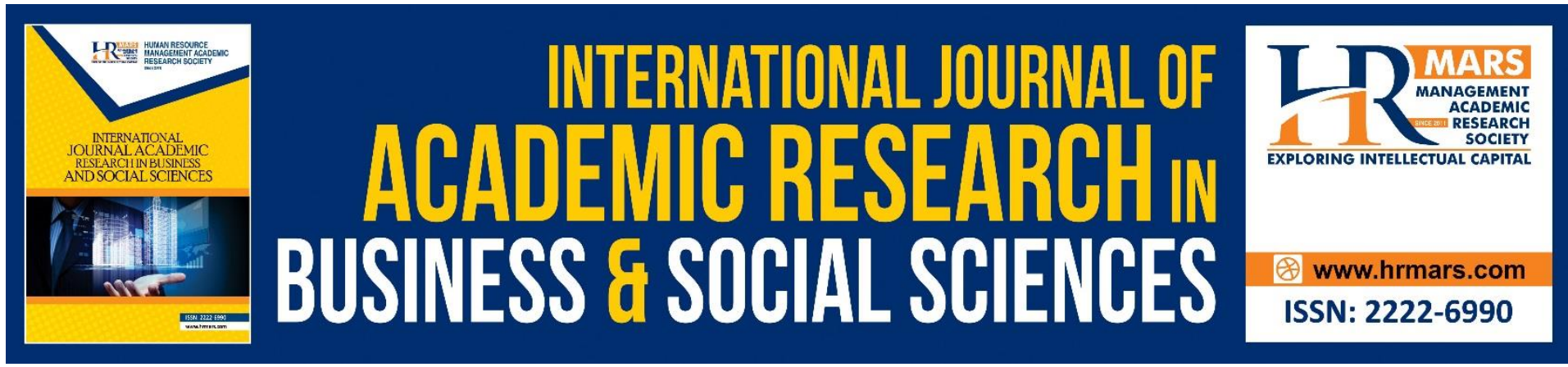

\title{
Public Expenditure and Economic Growth Relationship: Further Evidence from Nigerian Context
}

\author{
Nnachi Egwu Onuoha \\ Department of Accountancy/ Banking and Finance, Alex-Ekwueme Federal University, \\ Ndufu-Alike, Ebonyi State, Nigeria \\ Email: ennachix@yahoo.com
}

\section{Gregory Onuora Okoye}

Department of Accountancy, Madonna University, Okija, Anambra State, Nigeria

Email: Okoyegreg01@gmail.com

\begin{abstract}
In response to inconclusive findings by extant empirical studies on government spendingeconomic growth nexus, this study explores the effects of aggregate public expenditure, recurrent government expenditure and capital government expenditure on economic growth, and the effect of economic growth on aggregate public expenditure. Using a time series data set from Nigerian context for the period between 1981 and 2018 and analysing same with OLS regression model after a pre-estimation unit root test, an impressive results emerged. First, the study found that whereas aggregate public expenditure positively affects economic growth, recurrent government expenditure and capital government expenditure have insignificant effects on economic growth. Second, the study found that economic growth positively affects government spending. These results offer an insight that would enable fiscal policy makers to insist on improved government spending.

Keywords: Expenditure, Public Expenditure, Economic Growth, Fiscal Policy
\end{abstract}

\section{Introduction}

Although Nigeria has arguably been regarded as the biggest economy in West Africa, as oil is the mainstay of Saudi Aribia's economy (Alshahrani \& Alsadiq, 2014), so also the Nigerian economy is heavily dependent upon oil. Consequently, revenue from oil constitutes the largest percentage of the total revenue that accrues to Nigeria annually. One of the key components of Nigerian macroeconomic fiscal policy to direct and control the economy is public expenditure. Clearly, any sectorial categorization of such integrated system as economy, whether Nigeria's or not, will undoubtedly lead to public and private sectors with the former often regarded as that component of the economic activity under the direction and control of the government. However, governmental activities extend well beyond just economic activities. Activities that are political, social, technological, etc., form part of the 
multiplicities of governmental activities. Depending upon what is considered a priority activity to meet the ever widening needs of the people, governments are often constrained by the paucity of resources. These activities seem to have been evolving over the years in response to the endless needs of the people. Thus, later days governmental activities appear wider than those of the former.

Akrani (2011a) states that Adam Smith documented in his 'Wealth of Nations' that the government ought to limit their activities to: maintenance of internal peace and order, defence against foreign aggression and public development work. All other functions besides these, according to the author, were viewed as beyond the scope of the state and any expenditure incurred on them was seen as unjust and wasteful. Nowadays, there seems to be increase in public expenditure especially in developing nations of the world, among which Nigeria belongs. This increase in government expenditure, no doubt, is consequent upon increase in government involvement in many activities, some of which have the potential to enhance the living standard of her subjects. In developing countries, public spending policy does not only promote employment opportunities and speed up economic growth, but also plays a useful role in decreasing poverty and inequalities in income level (Akrani, 2011b). Implicit from the foregoing is that increased public expenditure of governments especially developing countries, as Nigeria, is a result of its increased key use as fiscal policy to determine the level of income and ultimately grow the national economy. In Nigeria, public expenditure has continued its upward match. This continues increase in the expenditure (currently it runs in trillions of naira) does not seem to be reflected in the economic growth of the country as published indices indicate. However, whether or not a relationship exists between public expenditure and economic growth has continued to generate controversies among researchers and theorists.

Empirical evidence indicating that public expenditures are growth- retarding (Kweka \& Morrissey, 2000; Egbetunde \& Fasanya, 2013) abounds as much as those of growth enhancing (Dandan, 2011; Oni \& Ozemhoka, 2014; Yilgör, Ertugrul \& Celepcioglu, 2012). As stated by Kweka and Morrissey (2000), even though many studies have been carried out, consistent evidence does not exist for a significant association amongst public expenditure and economic growth, in a negative or positive direction, and empirical results vary by analytical method employed, country or region and classification of public spending. The coauthors further stated that whereas Folster and Henrekson (1999) argue that the relationship is negative, Agellet al (1999) respond that it is not significant. Specifically, there is no agreement regarding the direction of the causal relationship between public spending and economic growth. This mixed finding is, according to Folster and Henrekson (1999, as cited in Kweka \& Morrissey, 2000), attributed to likely endogeneity problem in regression analysis. This, no doubt, has engendered conflicting study results (Muthui, Kosimbei, Maingi \& Thuku, 2013). Additionally, the real relationship among public spending and growth is not well understood and, as a result, there is a need for more empirical research (Grier \&Tullock, 1989, as cited in Kweka \& Morrissey, 2000).

Specifically, the size of government spending and its effect on economic growth continues to engage the attention of researchers. As rightly observed by Loizides and Vamvoukas (2005), an issue of sustained interest for decades is the size of government expenses and its impact on long-term economic growth. Consequently, this study explores:

- the effect of aggregate public expenditure on economic growth;

- the effect of recurrent government expenditure on economic growth;

- the effect of capital government expenditure on economic growth and 
- the effect of economic growth on total public expenditure, using further evidence from Nigeria context.

The study found that: aggregate public expenditure positively affects economic growth, recurrent government expenditure and capital government expenditure have insignificant effect on economic growth, and economic growth (increase in gross domestic product) also increases government spending.

This study contributes empirically and theoretically. By investigating: the effect of aggregate public expenditure on economic growth; the impact of recurrent government expenditure on economic growth; the effect of capital government expenditure on economic growth and the impact of economic growth on total public expenditure, using further evidence from Nigeria context, the study makes empirical contribution. The study makes theoretical contribution by further validating both Wagner and Keynesian theories as strong frameworks for understanding and explaining government spending and economic growth relationship.

The remainder of this paper is organized as follows. Whereas section two presents Literature review and hypotheses development, section three details the methodology of the study. Thereafter, sections four and five present results and conclusion, respectively.

\section{Literature Review and Hypotheses Development}

\section{Public Expenditure, Economic Growth and Fiscal Policy}

The concept of Public Expenditure is often used to denote government expenditure. According to Akrani(2011b), any expenditure incurred by such public authorities as local, state and central governments to meet the joint social wants of the general public is recognized as public expenditure. These collective social wants take different forms. The provision of these wants is regarded as part of the legitimate critical roles any responsible government is expected to play. Identifying these roles Taiwo (2011, p. 22) documents: "Government spending as a fiscal instrument serves useful roles in the process of controlling inflation, unemployment, depression, balance of payment equilibrium and foreign exchange rate stability". When there is depression as well as unemployment, public expenditure often leads total demand to increase, with production of goods and supply of same and service following in the similar direction (Taiwo, 2011).

However, depending on the fiscal objectives of government, this public expenditure takes different classifications. Classification of Public expenditure, according to Akrani (2011b), refers to the systematic arrangement of different items on which the government incurs expenditure. The author further identified these arrangements by different economists as: revenue and capital expenditure; functional classification; transfer and non-transfer expenditure; development and non-development expenditure; productive and unproductive expenditure; grants and purchase price; Hugh Dalton's classification of public expenditure and classification according to benefits. In the Nigerian context, the classification seems to be based on the nature of the expenditure in question. According to Taiwo (2011), public expenditure in Nigeria is broadly categorised into recurrent and capital expenditure, and whereas the recurrent expenditure are government expenditures incurred on such administrative items as wages and salaries, maintenance, interest on loans, etc., capital expenditure are expenses on such capital projects as roads, education, airports, electricity generation and telecommunication, etc..These public expenditures are often expected to drive economic growth. 
According to Tucker (2009), economic growth is an increase in the nationwide output often calculated using the annual percentage rise in a given nation's real GDP. The author further states that economic growth is the capacity of any given economy to produce higher levels of output which is often represented through an outward shift of her production possibility curve. In the words of Colander (2010, p. 547), "economists measure growth with changes in real GDP - the market value of the final goods and services produced in an economy, stated in the prices of a given year". The author views real GDP as any GDP adjusted for changes in price. Ofili (2014) listed the approaches to compilation of GDP as: expenditure approach; Production approach and income approach. Expenditure approach, according to the author, involves measuring GDP as the sum of final consumption, gross fixed capital formation and net export.

Depending upon the situation on the ground, governments can shape and reshape their economic objective to suit that situation. To achieve this objective, government makes use of economic instruments. As an example, to realize high employment objective, government might boost the national economy by means of fiscal policy instruments (Artkinson, Baker \& Milward, 1996). Fiscal policy has been viewed as referring to that government's choices regarding how much to tax and how much to spend (Case, Fair \& Oster, 2013; Frank \& Bernanke, 2013). Additionally, fiscal policy has been identified by Frank and Bernanke (2013) as one of the very many key stabilization policies. According to the co-authors, stabilization policies refer to government policies that are often utilized to affect planned total expenditure with the aim of removing output gaps. Fiscal policy could be expansionary and contractionary, with the expansionary variety being referred to, according to Case, et al. (2013), as a policy in which involves either taxes cut or government spending increases or both. So, the influence of this government or public spending on GDP is what this study seeks to explore.

\section{Hypotheses Development}

Existing body of literature on public expenditure-economic growth relationship indicates rising empirical studies (see, for example, Devarajan, Swaroop \& Zou, 1996; Kweka \& Morrissey, 2000; Gong \& Zou, 2002; Loizides \&Vamvoukas, 2005; Dandan, 2011; Nworji, Okwu, Obiwuru \& Worji, 2012; Yilgör, et al., 2012; Egbetunde \& Fasanya, 2013; Okoro, 2013; Muthui, et al., 2013; Oyinlola \& Akinnibosun, 2013; Oni, \& Ozemhoka, 2014). Specifically, Devarajan, et al., (1996) explored the relation that subsists among economic growth and the composition of public expenditure and indicated that increase in current expenditure has significant positive effect on growth. They also found the relationship between capital expenditure and per-capita growth to be negative. Kweka and Morrissey (2000) investigated Government Spending - Economic growth relationship using evidence from Tanzania and showed that whereas increased productive expenditure is negatively related to growth, consumption expenditure is related positively to growth. Exploring the effect of instability in government expenditures on economic growth, Gong and Zou (2002) found no association between growth in capital expenditure and economic growth. They also showed that growth in recurrent expenditure could stimulate economic growth. Loizides and Vamvoukas (2005) explored the relationship between government expenditure and economic growth using evidence from Greece, Ireland and United Kingdom and found causal relationship between government size and economic growth. They also indicated that economic growth is important in determining the size of government in Greece and the UK. 
Nworji, et al. (2012) investigated the relation between public expenditure and economic growth using evidence from Nigeria and showed that whereas both recurrent and capital expenditure are negatively related to economic growth, capital expenditure on transfers is positively related to growth. They also indicated that capital and recurrent expenditures incurred on social and community services and recurrent expenditure on transfers are positively related to economic growth. Using evidence from Turkey, Yilgor, et al. (2012) explored the effect public expenditure has on economic growth and found a causal relationship between transfer, current and total expenditures and economic growth. However no causal relationship was found to exist between investment expenditures and economic growth by the co-authors.

Further, Egbetunde and Fasanya (2013), using evidence from Nigeria, explored economic growth and public expenditures relation and found that whereas total public spending has negative effect on economic growth, in disaggregated form, recurrent expenditure has positive impact on economic growth. Muthui, et al. (2013) studied the effect of the components of public expenditure on economic growth using evidence from Kenya and found that government expenditure incurred on education has insignificant positive effect on economic growth. Oni and Ozemhoka (2014) explored the effect of public expenditure on economic growth using evidence from Nigeria and indicated that a positive relationship exists between economic growth and government expenditure.

Iyodo, Samuel, Adewole and Ola (2020) examined the effect of non-life insurance penetration could have on economic growth using Nigerian context and demonstrated that, amongst others, non-life insurance penetration is important in the decision to increase economic growth in Nigeria. The authors further indicated that government expenditure has insignificant negative effect on the economic growth of Nigeria. Dandan (2011) investigated government spending and economic growth relationship using evidence from Jordan and showed that aggregate government spending positively impact on economic growth. Oyinlola and Akinnibosun(2013) explored Public expenditure - economic growth relationship using evidence from Nigeria and indicated that economic growth plays significant role in deciding the level of government expenditure in Nigeria.

From the above reviewed empirical studies, it would be observed that, overall, whereas some studies found public expenditures to be growth- retarding (Kweka \& Morrissey, 2000; Nworji, et al., 2012; Egbetunde \& Fasanya, 2013; lyodo, et al., 2020), others found public expenditure to be growth -enhancing (Dandan, 2011; Oni, \& Ozemhoka, 2014; Yilgör, et al., 2012). This mixed finding has engendered an inconclusive result situation. Additionally, while, "Wagner theory postulates that the government expenditure increases as a result of industrial and economic growth in a country" (Uchenna \& Evans, 2012, p. 29), Keynesian theory states that government expenditure boosts economic growth (Muthui, et al., 2013). So, the mixed finding and the opposing positions of both Wagner and Keynesian theories with respect to the direction of causality among government expenditure and economic growth call for an empirical re-examination of this relationship. Accordingly, the hypotheses that follow are stated to guide this study.

H1: Total public expenditure has significant positive effect on economic growth.

$\mathrm{H} 2$ : Government recurrent expenditure has significant positive effect on economic growth.

H3: Government capital expenditure has significant positive effect on economic growth. 
H4: Economic growth has significant positive effect on total public expenditure.

\section{Methodology}

Data

To test the four hypotheses formulated above and ultimately achieve the study objectives, a time series data set was collected from the 2018 Central Bank of Nigeria (CBN) statistical bulletin. The collected data set was subjected to a preliminary unit root test to ascertain stationarity using the Augmented Dickey-Fuller (ADF) test. Unit root test is conducted to, according to Oyinlola and Akinnibosun (2013), evade the problem related to spurious regression.

The result of the test is presented in table 1 . From this table, it would be seen that The ADF test shows the presence of unit root in capital expenditure time series data at level. This is because the test statistic for this series is 1.514 , which is lower than the critical value $(-1.950)$ at $5 \%$ level of significance. However, at the first difference, capital expenditure time series data is stationary or there is no unit root. The table also indicates that the test statistics for GDP, recurrent expenditure (REXP) and total expenditure (TEXP) time series data at level are $2.828,4.779$ and 4.526 , respectively. This further indicates that the series are stationary or no unit root exits in them, since there are higher than the critical value of -1.950 . Consequently, a multiple regression analysis was conducted

Table 1: Unit root test results

\begin{tabular}{lrccc}
\hline & \multicolumn{2}{l}{ Level } & \multicolumn{2}{c}{ First Difference } \\
Variables & \multicolumn{1}{l}{ Test Stat. } & Critcal Val & Test Stat. & Critcal Val \\
\hline GDP & 2.828 & -1.950 & - & - \\
REXP. & 4.779 & -1.950 & - & - \\
CEXP. & 1.514 & -1.950 & -2.732 & -1.950 \\
TEXP. & 4.526 & -1.950 & - & - \\
\hline \hline
\end{tabular}

Source: Authors' compilation from STATA (Version 13.0) output

\section{Model Specification}

Following is the specification of the model for the study.

Mathematically,

$E G=f(T G E x, C E x, R E x)$

Equation one is transforming as follows:

$E G=a_{1}+a_{2} T G E x+a_{3} C E x+{ }_{a 4} R E x$

Equation two is further transformed econometrically as follows:

$E G=a_{1}+a_{2}$ TGEx $+a_{3} C E x+a_{4} R E x+U$

Where:

$E G=$ Economic Growth (proxied with gross domestic product)

TGEx $=$ Total or Aggregate Government Expenditure

CEx $=$ Total Capital Expenditure

REx $=$ Total Recurrent Expenditure

$\mathrm{U}=$ The error term 
$\mathrm{a}_{1}=$ The intercept

$a_{2}, a_{3}$, and $a_{4}=$ Coefficients of the independent variables.

Also, by modifying model 3 above using total or aggregate government expenditure as the dependent variable and EG as the independent variable we have model 4 as follows.

TGEx $=\mathrm{a} 1+\mathrm{a}_{2} \mathrm{EG}+\mathrm{U}$

Where TGEx, EG and $U$ remain as specified above.

The results of the estimation of Model 3 are deployed to test hypotheses 1, 2, and 3, while the result of the estimation of Model 4 is deployed to test hypothesis 4 . Following the prior empirical findings by Oni and Ozemhoka(2014) and Yilgör, et al. (2012), Keynesian theory, we expect that the coefficients of both total government expenditure and its components (capital and recurrent expenditure) $\left(a_{2}, a_{3}\right.$, and $\left.a_{4}\right)$ to be positive. Conversely, based on the prior empirical finding by Kwekaand Morrissey (2000), Nworji, et al. (2012) and Egbetunde andFasanya (2013), we expect the coefficients of both total government expenditure and its components (capital and recurrent expenditure) $\left(a_{2}, a_{3}\right.$, and $\left.a_{4}\right)$ to be negative. Following Wagner theory, it was expected that the coefficient of economic growth variable $\left(a_{2}\right)$ in model 4 would be positive.

\section{Results}

The study results are presented descriptively and inferentially.

\section{Descriptive Analysis}

Table 2 presents the descriptive statistics for the study variables. From this table, it would be seen that the average values of gross domestic product, recurrent expenditure, capital expenditure and total expenditure for the 38 years studied are 27569.4, 1286.98, 426.227and 1838.96 billion naira, respectively. This indicates that the average value of recurrent expenditure is higher than the average value of capital expenditure, suggesting that Nigerian government does not emphasize more on developing capital infrastructure.

Table 2:Descriptive Statistics

\begin{tabular}{lcccc}
\hline & $\begin{array}{c}\text { Minimum } \\
\text { (\#'Billion) }\end{array}$ & $\begin{array}{c}\text { Maximum } \\
\text { (\#'Billion) }\end{array}$ & $\begin{array}{c}\text { Mean } \\
\text { (\#'Billio }\end{array}$ & $\begin{array}{c}\text { Standard Deviation } \\
\text { (\#'Billion) }\end{array}$ \\
\hline Gross Domestic Product & 144.83 & 127763 & 27569.4 & 37734.9 \\
Recurrent expenditure & 4.75 & 5675.19 & 1286.98 & 1637.93 \\
Capital Expenditure & 4.1 & 1682.1 & 426.227 & 441.891 \\
Total Expenditure & 9.64 & 7813.74 & 1838.96 & 2239.54 \\
\hline \hline
\end{tabular}

Source: Authors' Compilation from STATA (Version 13) output

\section{Inferential Analysis}

Table 3 presents the result of the inferential analysis conducted. From this table, it would be observed that the coefficients of recurrent expenditure, capital expenditure and total expenditure are $0.353,-0.198$ and 0.662 , respectively. The table also shows that the corresponding $p$-values of these coefficients are $0.160,0.174$ and 0.014 . This shows that whereas government recurrent expenditure has insignificant positive effect on GDP, 
government capital expenditure has insignificant negative effect on GDP. These findings do not support hypotheses two(H2), which state that Government recurrent expenditure has significant positive effect on economic growth, and three (H3), which state that Government capital expenditure has significant positive effect on economic growth. The table further indicates that total government expenditure has significant positive effect on GDP. This finding supports hypothesis one $(\mathrm{H} 1)$ that total public expenditure has significant positive effect on economic growth.

The positive relationship between recurrent expenditure and economic growth is consistent with finding from prior study by Egbetunde and Fasanya (2013) that recurrent expenditure is positively related to economic growth. The positive effect which total public expenditure is found to have on economic growth is consistent with findings from prior studies (see, for example, Dandan, 2011; Yilgor, et al., 2012; Oni, \& Ozemhoka, 2014) that aggregate government spending positively impact on economic growth. Conversely, this result is inconsistent with findings from prior studies conducted by Kweka and Morrissey (2000), Nworji, et al.(2012), Egbetunde and Fasanya (2013) and lyodo, et al. (2020) that total government spending negatively impacts on economic growth. Further, whereas the positive effect which total government expenditure is found to have on economic growth supports Keynesian theory which, according to Muthui, et al.(2013), states that government expenditure boosts economic growth, it does not support Wagner theory which, according Uchenna and Evans (2012), states that economic growth positively affects aggregate government expenditure.

Table 3: Multiple Regression Result

\begin{tabular}{|c|c|c|c|c|}
\hline \multirow{2}{*}{$\begin{array}{l}\text { Dependent variable } \\
\text { Independent variables }\end{array}$} & & \multicolumn{3}{|c|}{ Gross Domestic Product } \\
\hline & & Coefficients & T-Values & P-Values \\
\hline Recurrent Expenditure & & 0.353 & 1.44 & 0.160 \\
\hline Capital Expenditure & & -0.198 & -1.39 & 0.174 \\
\hline Total Expenditure & & 0.662 & 2.58 & 0.014 \\
\hline Constant & & 1.131 & 11.8 & 0.000 \\
\hline R-Squared & 0.988 & & & \\
\hline F-value & 867.2 & & & \\
\hline P-value & 0.000 & & & \\
\hline
\end{tabular}

Source: Authors' compilation from Stata version 13.0

Table 4 further presents the result of the inferential analysis conducted. From this table, it would be observed that the coefficient of gross domestic product variable is 0.059 , while its corresponding $\mathrm{p}$-value is 0.000 . This shows that economic growth has significant positive effect on government capital expenditure. This finding supports hypothesis four $(\mathrm{H} 4)$ which states that economic growth has significant positive effect on total public expenditure.

The significant positive effect which economic growth is found to have on government capital expenditure is consistent with finding from a prior study by Oyinlola and Akinnibosun(2013) that economic growth plays significant role in deciding the level of government spending. Also, this finding supports Wagner theory which states that "the government expenditure increases as a result of industrial and economic growth in a country" (Uchenna\& Evans, 2012, p. 29) 
Table 4: Multiple Regression Result

\begin{tabular}{lccc}
\hline Dependent variable & $\begin{array}{l}\text { Total Government } \\
\text { Expenditure } \\
\text { Coefficients }\end{array}$ & T-Values & P-Values \\
Independent variables & 0.059 & 36.02 & 0.000 \\
\hline Gross Domestic Product & 224.98 & 2.99 & 0.005 \\
Constant & 0.973 & & \\
R-Squared & 1297.4 & & \\
F-value & 0.000 & & \\
P-value & & \\
\hline \hline
\end{tabular}

Source: Authors' compilation from STATA version 13.0

The results of the study is consistent with a priori expectation that the coefficients of both total government expenditure and recurrent expenditure would be positive, following Keynesian theory, and the coefficient of GDP will be positive, in line with Wagner theory. Overall, the findings indicate that a positive relationship exists between public expenditures and economic growth. These results suggest that whereas public expenditures positively influence economic growth, economic growth also positively affects public expenditures. These results further indicate that Keynesian and Wagner theories are robust frameworks for explaining public spending-economic growth nexus.

\section{Conclusion}

The study explores: the effect of aggregate public expenditure on economic growth; the impact of recurrent government expenditure on economic growth; the effect of government capital expenditure on economic growth and the impact of economic growth on total public expenditure, using further evidence from Nigerian context. It is found, among others, that aggregate public expenditure positively affects economic growth. This finding suggests that government spending plays significant role in growing the economy. The study further found that, recurrent government expenditure and capital government capital expenditure have insignificant effect on economic growth. This finding very clearly suggests that the effect of government spending on economic growth can only be significant when viewed from aggregate perspective. Furthermore, it is observed that economic growth or increase in gross domestic product also increases government spending. This finding also suggests that a causal relationship exists between public expenditure and economic growth, with economic growth being the causal variable while total government expenditure is the effect variable.

The study has two practical implications. First, the study outcome that the aggregate public expenditure positively affects economic growth would offer strong basis for fiscal policy makers to understand and insist on improved government spending. Second, the outcome that the economic growth or increase in gross domestic product increases government spending would also serve as robust empirical basis for fiscal policy makers to understand the need to insist that increased government income resulting from increased gross national product should be utilised to improved government spending.

This study has two limitations. First, the study focused on Nigerian context. Second, the study concentrated on a time period (from 1981 to 2018) that covers 38 years. Consequently, to attain a better and generalizable result, future studies on 'government spending-economic 
growth nexus' should include other African countries and increase the number of years (from 1970 to the present).

\section{Significant Contributions}

The study contributes theoretically and empirically. First, the study result that government spending positively relates to economic growth provides further empirical evidence to support Wagner and Keynesian theories and, thus, indicates that both theories are strong frameworks for explaining public spending-economic growth relationship. Second, by exploring government spending-economic growth nexus using further evidence from Nigerian context, this study contributes not only to extant literature on public expenditure and economic growth relationship, but provides invaluable insights for fiscal policy makers in Nigeria.

\section{References}

Alshahrani, S. A., \& Alsadiq, A. J. (2014). Economic Growth and Government Spending in Saudi Arabia: an Empirical Investigation, International Monetary Fund WP.

Artkinson, B., Baker, P., \& Milward, B. (1996). Economic Policy. London: MACMILLIAN Press Ltd.

Akrani G. (2011a). Wagner Law of Increasing State Activity- Public expenditure. Retrieved from https://kalyan-city.blogspot.com/2011/02/wagner-law-of-increasing-stateactivity.html

Akrani, G. (2011b). What is Public Expenditure? Meaning, Definition. Retrieved from https://kalyan-city.blogspot.com/2011/02/what-is-public-expenditure-meaningand.html

Case, K. E., Fair, R. C., \& Oster, S. M. (2013). Principles of Economics. 10 ${ }^{\text {th }}$ Edt., England: Pearson Education Ltd.

Colander, D. C. (2010). Economics (Eight Ed.). USA: McGraw-Hill Companies Inc.

Dandan, M. M. (2011). Government Expenditures and Economic Growth in Jordan. 2011 International Conference on Economics and Finance Research IPEDR, 4, 467-471.

Darwish, S., Ahmed, U., \& Pahi, M. H. (2020). Innovative Work Behavior During COVID-19 for Medical Representative in the Pharmaceutical Industry: Test of a Moderation Model in Bahrain. International Journal of Pharmaceutical Research. 12(4), 19271934. doi.org/10.31838/ijpr/2020.12.04.277

Devarajan, S., Swoop, V., \& Zou, H. (1996). The composition of public expenditure and economic growth. Journal of Monetary economics, 37, 313-344.

Egbetunde, T., \& Fasanya, I. O. (2013). Public Expenditure and Economic Growth in Nigeria:Evidence from Auto-Regressive Distributed Lag Specification. Zagreb International Review of Economics \& Business, 16(1),.79-92,

Frank, R. H., \& Bernanke, B. S. (2013). Principles of Economics. $5^{\text {th }}$ Edt., New York: McGrawHill.

Gong, L., \& Zou, H. (2002). Effects of Growth and Volatility in Public Expenditures on Economic Growth: Theory and Evidence. Annals of Economics and Finance, 3, 379-406.

Iyodo, B. Y., Samuel, S. E., Adewole, C., \& Ola, P. O. (2020). Impact of Non-life Insurance Penetration on the Economic Growth of Nigeria. Research Journal of Finance and Accounting, 11(2), 40-50. 
Kweka, J. P., \& Morrissey, O. (2000). Government Spending and Economic Growth in Tanzania, 1965-1996. UK: Centre for Research in Economic Development and International Trade, University of Nottingham.

Loizides, J., \& Vamvoukas, G. (2005). Government Expenditure and Economic Growth: Evidence fromTrivariate Causality Testing,Journal of Applied Economics, 8(1), 125$152 . S$

Muthui, J. N., Kosimbei, G., Maingi, J., \& Thuku, G. K. (2013). The Impact of Public Expenditure Components on Economic Growth in Kenya 1964-2011.International Journal of Business and Social Science, 4(4),233-253.

Nworji, I. D., Okwu, A. T., Obiwuru, T. C., \& worji, L. O. (2012). 'Effects of Public Expenditure on Economic Growth in Nigeria: a disaggregated time series analysis. International Journal of Management Sciences and Business Research, 1(7), 1-15.

Ofili, E. G. (2014). Basics and Computation of Rebased Gross Domestic Product (GDP) Nigeria's Experience. Bullion (CBN Publication), 38(2), 47- 53.

Okoro A. S. (2013). Government Spending and Economic Growth in Nigeria, (1980-2011), Global Journal of Management and Business Research, 13(5), 21-30

Oni, A. A., \& Ozemhoka, A. M.(2014). Impact of Public Expenditure on the Growth of Nigerian Economy. European Scientific Journal, 10(28), 219-229.

Oyinlola, M. A., \& Akinnibosun, O. (2013), Public expenditure and economic growth nexus: Further evidence from Nigeria. Journal of Economics and International Finance, 5(4), 146-154.

Tucker, I. V. (2009). Essentials of Economics (sixth Ed.). USA: South-Western Cenage Learning.

Taiwo, M. (2011). Government Expenditure and Economic Development: Empirical Evidence from Nigeria. European Journal of Business and Management, 3(9), 2011, 18-28.

Uchenna, E., \& Evans, O. S. (2012). Government Expenditure in Nigeria: An Examination of TriTheoretical Mantras. Journal of Economic and Social Research, 14(2), 27-52.

Wijeweera, A., \& Garis, D. (2009). Wagner's law and social welfare: the case of the kingdomof saudiarabia. Applied Econometrics and International Development, 9(2), 199-209

Yilgör, M., Erturul, C., \& Celepciolu, M. E. (2012). The Effect of Public Expenditure on Economic Growth: Turkey example. Investment Management and Financial Innovations, 9(2), 193- 202. 